\title{
GOOGLE EARTH: INSPIRATION AND INSTRUMENT FOR THE STUDY OF ANCIENT CIVILIZATIONS
}

\author{
${ }^{1}$ Jaroslav KLOKOČNÍK, ${ }^{2}$ Jan KOSTELECKÝ, ${ }^{3}$ Karel PAVELKA
}

\author{
${ }^{1}$ Astronomical Institute, p.r.i., Academy of Sciences of the Czech Republic, \\ CZ-251 65 Ondřejov Observatory, Czech Republic, jklokocn@asu.cas.cz \\ ${ }^{2}$ Research Institute for Geodesy, Topography and Cartography, p.r.i., \\ CZ-250 66 Zdiby 98, Czech Republic kost@ fsv.cvut.cz \\ ${ }^{3}$ Czech Technical University in Prague, Faculty of Civil Engineering, \\ Thakurova 7, Prague 6, pavelka@fsv.cvut.cz
}

\begin{abstract}
Keywords: Google Earth, Nasca geoglyphs and petroglyphs (Peru), Chinese "pyramids"(Xi' an and Luoyang, central China), Monte Alban - Atzompa (Mexico), ancient roads (Yucatán, Mexico, Chaco valley, New Mexico).
\end{abstract}

\begin{abstract}
Satellite imaging is well known as a useful tool in many scientific disciplines and various applications. Google Earth, with its free access, is now - thanks to increasing resolution and precision - such a tool. It can be very inspiring. It improves the visualization and dissemination of scientific data, and opens doors to new discoveries. For example, many Nasca geoglyphs are now visible to Google Earth and so are the orientations of Chinese pyramids, which appear to be laid out with the aid of a magnetic compass. Google Earth also infor-med us about the "new" archaeological locality Atzompa close to the well known "Monte Alban" near Oaxaca (Mexico), which we then visited (in March 2010). Google Earth can also "see" prehistoric causeways in Mesoamerica, "sacbeob" and in the Chaco valley (New Mexico). We find that Google Earth can save time and resources to researches significantly: before, during and after field works and measurements; we present examples.
\end{abstract}

\section{INTRODUCTION}

The increasing resolution and precision of generic Google Earth (GE) on many places of the globe enables diverse, sometimes unexpected, applications. GE has the potential to improve the visualization and dissemination of scientific data in many fields [1]. Archaeology is one of these. Several examples of the use of GE for archaeo-astronomy and other studies of ancient civilizations will be discussed in this paper. Thus we used GE in places where we knew in advance what was on the ground (e.g., various localities in Mesoamerica and Peru), or where we later had satellite images with a higher resolution (Ikonos, Quickbird satellites; Nasca geoglyphs, Peru), but also over localities we had not yet visited (Xi'an, Luoyang, China) to prepare ourselves for possible future field measurements. This would use GE very efficiently, saving time and resources. It is well known, and documented by many examples, that 'birds-eye' views (from aircraft or satellites) can lead to actual discoveries, where our terrestrial views are limited (in a jungle for example). GE can also be considered as a first (informative) step for further analyses of better (but less accessible) satellite data, say from TerraSAR-X. In the following sections we present a collection of case studies, we consider examples of the use of GE data for the Nasca area (Peru), Section II; for the Chinese pyramids, Section III; Monte Alban - Atzompa (Mexico); Section IV, sacbeob (ancient "roads") hidden on the Yucatán, Section V; and on long straight lines near the Chaco Valley (New Mexico), Section VI. This paper is an extension of our presentation [2] at the "2010 Second International Conference on Advanced Geographic Information Systems, Applications, and Services" held in St. Maarten.

\section{NASCA GEOGLYPHS, PERU}

The desert between the towns of Nasca and Palpa, Peru has many huge geoglyphs (long lines, geometric features and figures generally of animals), mostly coming from the Nasca culture (about 1500-2000 years old), and illustrated by Fig. 1, or pre-Nasca cultures. Since their re-discovery for our civilization (during the first flights between Lima and south Peru) they were intensively studied and various theories as to their origin and meaning are still being debated. Some of the long straight lines (rays) are astronomically oriented [3], some geoglyphs (trapezoids) have evident relationship to underground water [4], [5], which was (and is) in this area a very limited resource. Older measurements 
and photo-documentation achieved with great effort by Marie Reiche and others [3], [6] have been significantly extended by the work of Prof. Bernd Teichert and his group from Dresden (e.g., [7] and their NascaWebGIS), by David Johnson and coworkers [4], and many others (for other information and references see [8]). For example we note the discovery that the famous tourist attraction on the pampa near the Nasca town, the geoglyph known (thanks to E. Däniken) as El Astronauto, is in fact (Fig. 2) a Fisherman [9], [10].

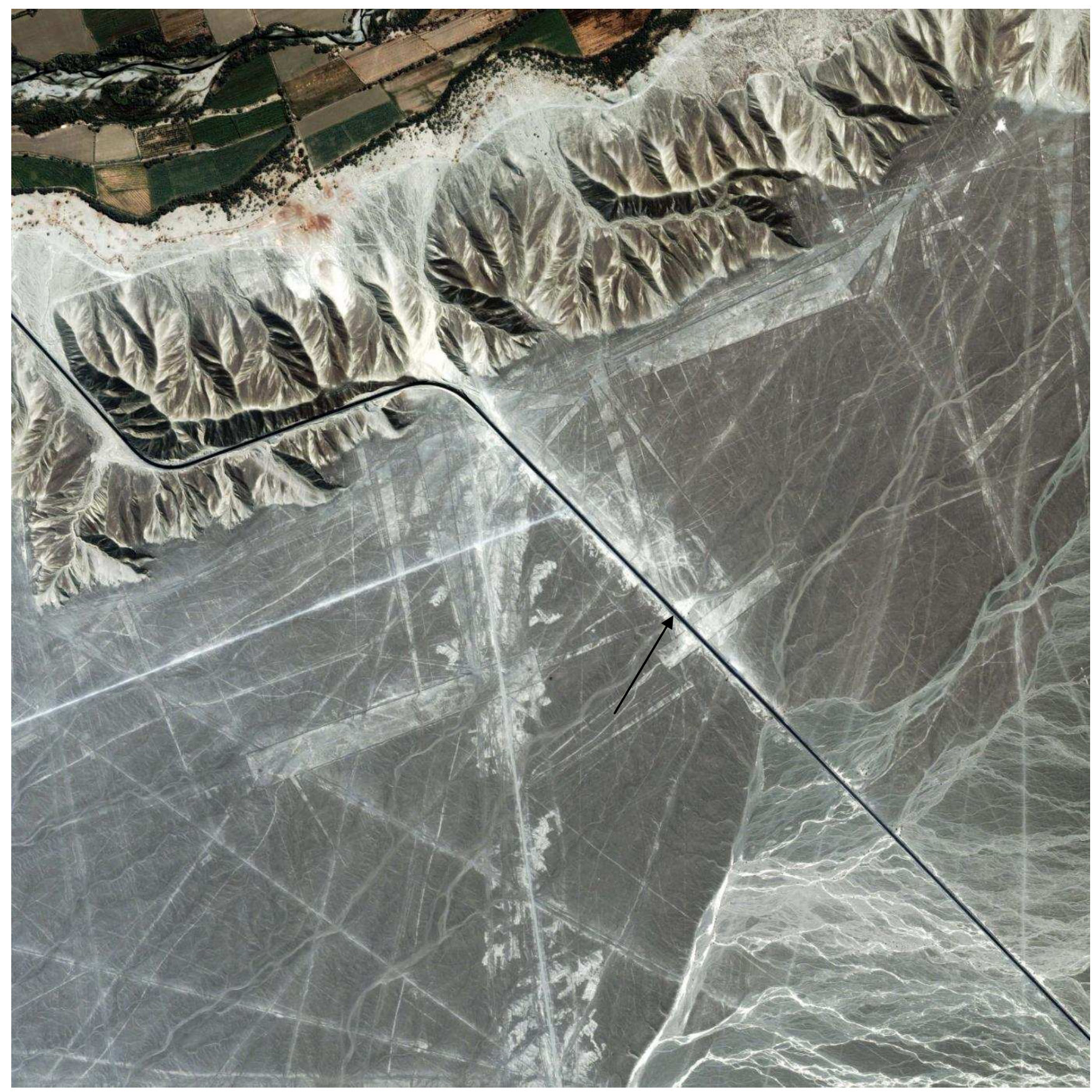

Figure 1. Many large geoglyphs on the pampa near Nasca, Here not from a plane but from satellite images via Google Earth. The trapezoid near the Pan-American road and tourist tower of Maria Reiche is arrowed. 


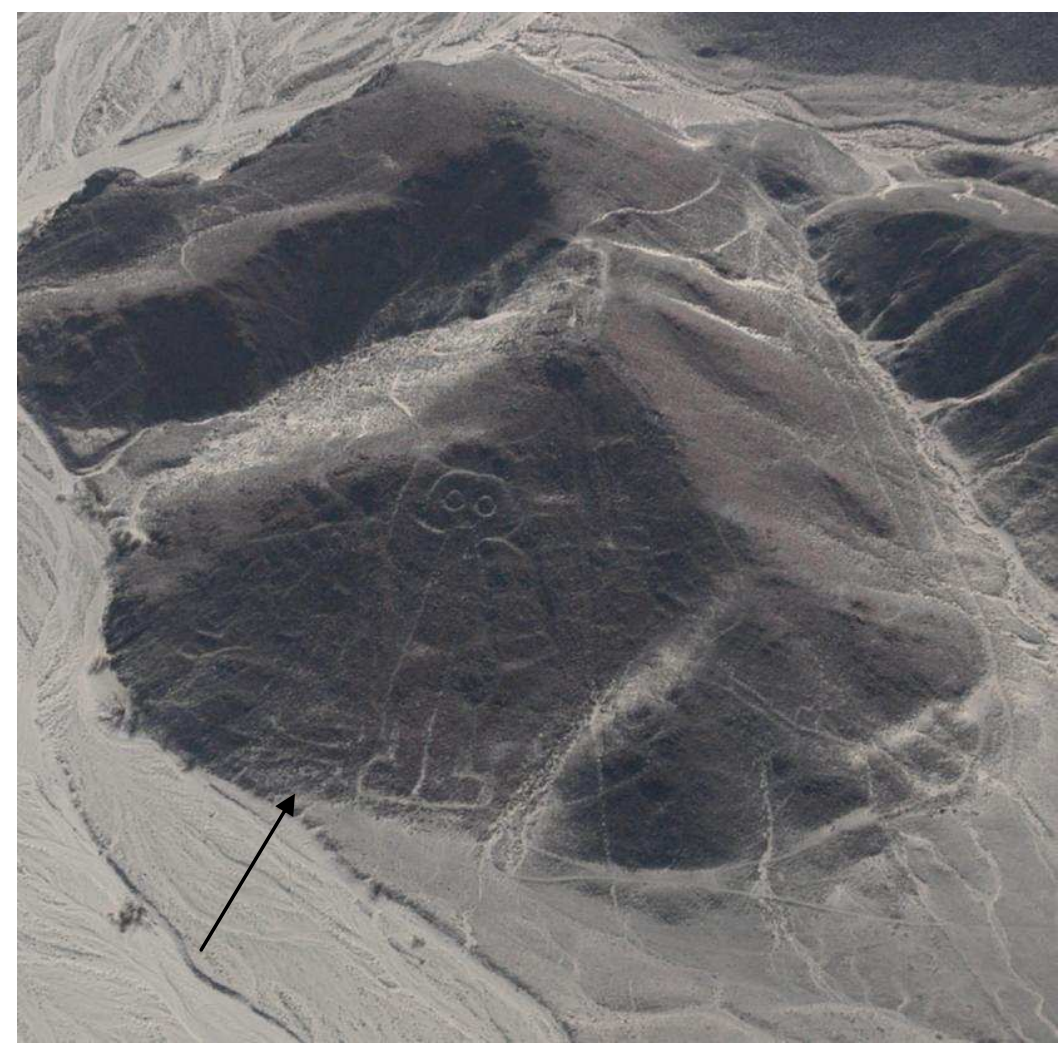

Figure 2. "El Astronauto" - "Fisherman", $30 \mathrm{~m}$ high geoglyph in the pampa near the town of Nasca, Peru [9], [10]. The fish is at the man's right leg (arrow). A snapshot from a plane, but the object (without details) is also visible by Google Earth.

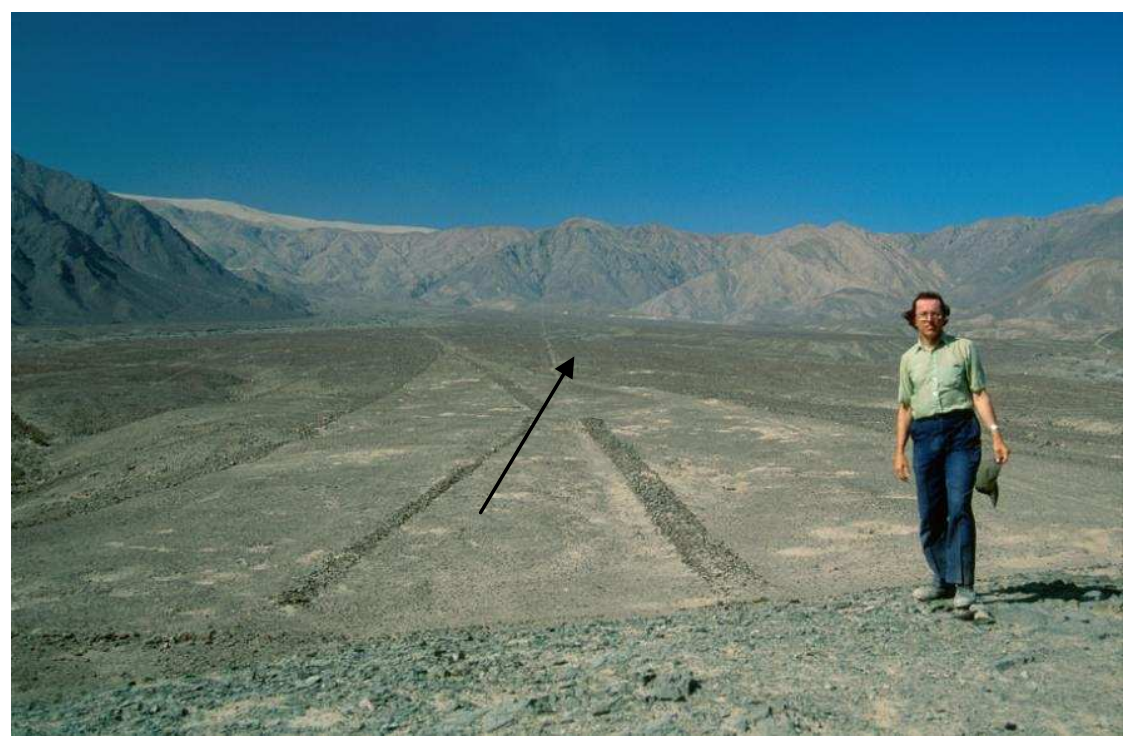

Figure 3. Geophyph - trapezoid near town Nasca, locality Cantayoc; width about $70 \mathrm{~m}$. Ground photo (C) J. Klokočník, 2001) from a small hill at the end of the geolyph. Cerro Blanco on left, D. Johnson on right hand side. The narrow line connects this place with the next hill (arrow). 


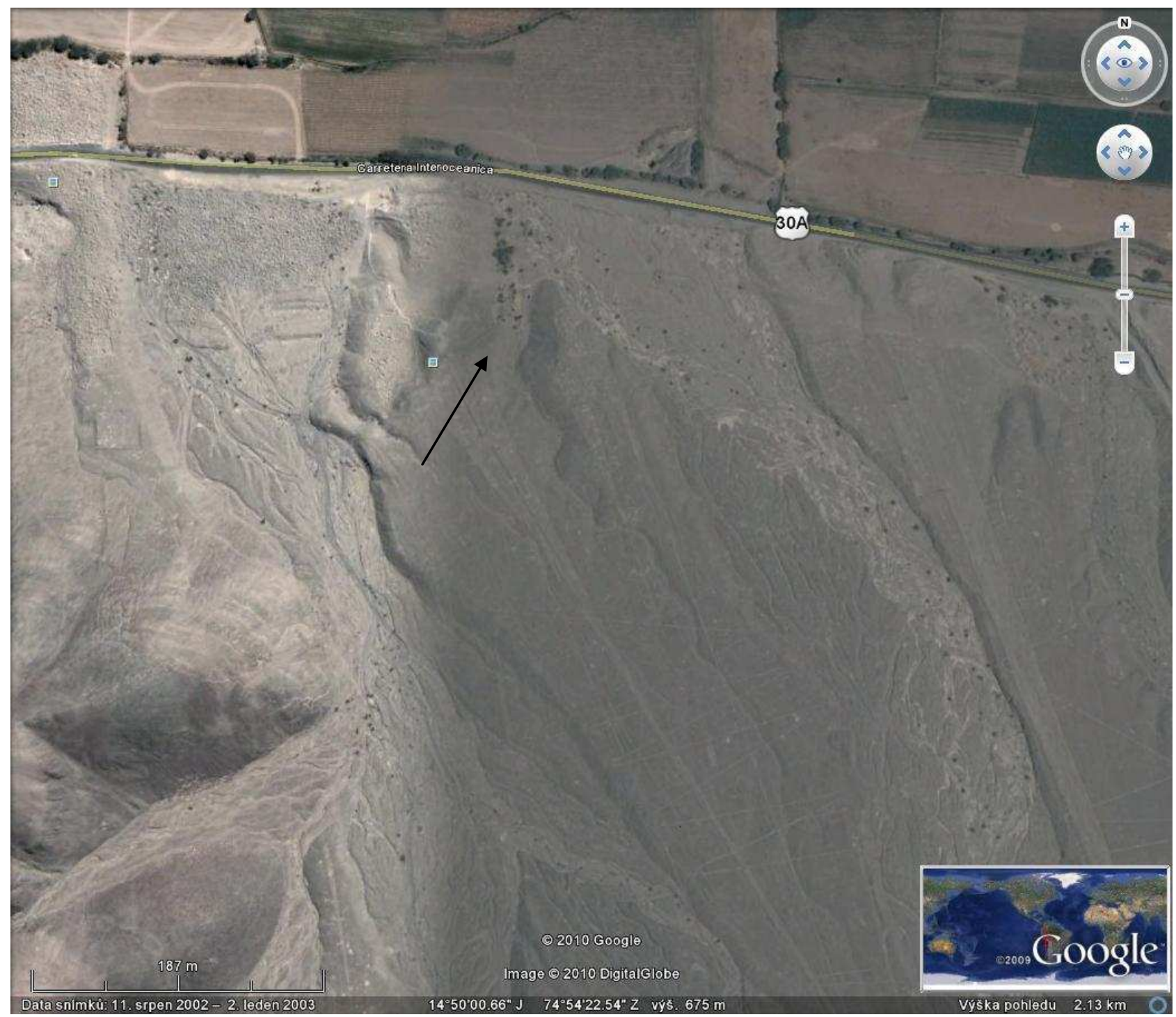

Figure 4. The same geoglyph on image from Google Earth. North is up. The arrow shows the place from which the photo reproduced in Fig. 3 was taken. Compare to the image of higher resolution, Fig. 5, next page.

With GE we can see the majority of the geoglyphs in the area without any measurements on site. We recommend the interactive map of Volker Arnold, or book [3]. Overall, GE is an invaluable tool for 'general views' as well as an introduction to deeper local studies with satellite images of higher resolution. East of the Nasca town there is a place called Cantayoc, located near a huge sand dune - the mountain Cerro Blanco. There is many known geoglyphs in this area. According to Johnson [3] they are (here and in the Pampa around towns Nasca and Palpa) related to the underground water (here to the aquifers coming from faults from the mountain). Fig. 3 shows one of the geoglyphs (trapezoid) from the ground, Fig. 4 the same place with GE and Fig. 5 again the same place in another zoom on satellite image (Ikonos-Quickbird) with a higher resolution (kindly provided by B. Teichert et al, 2009). In the west direction from Cerro Blanco, in a remote area, there are further geoglyphs, see, e.g., Fig. 6. 


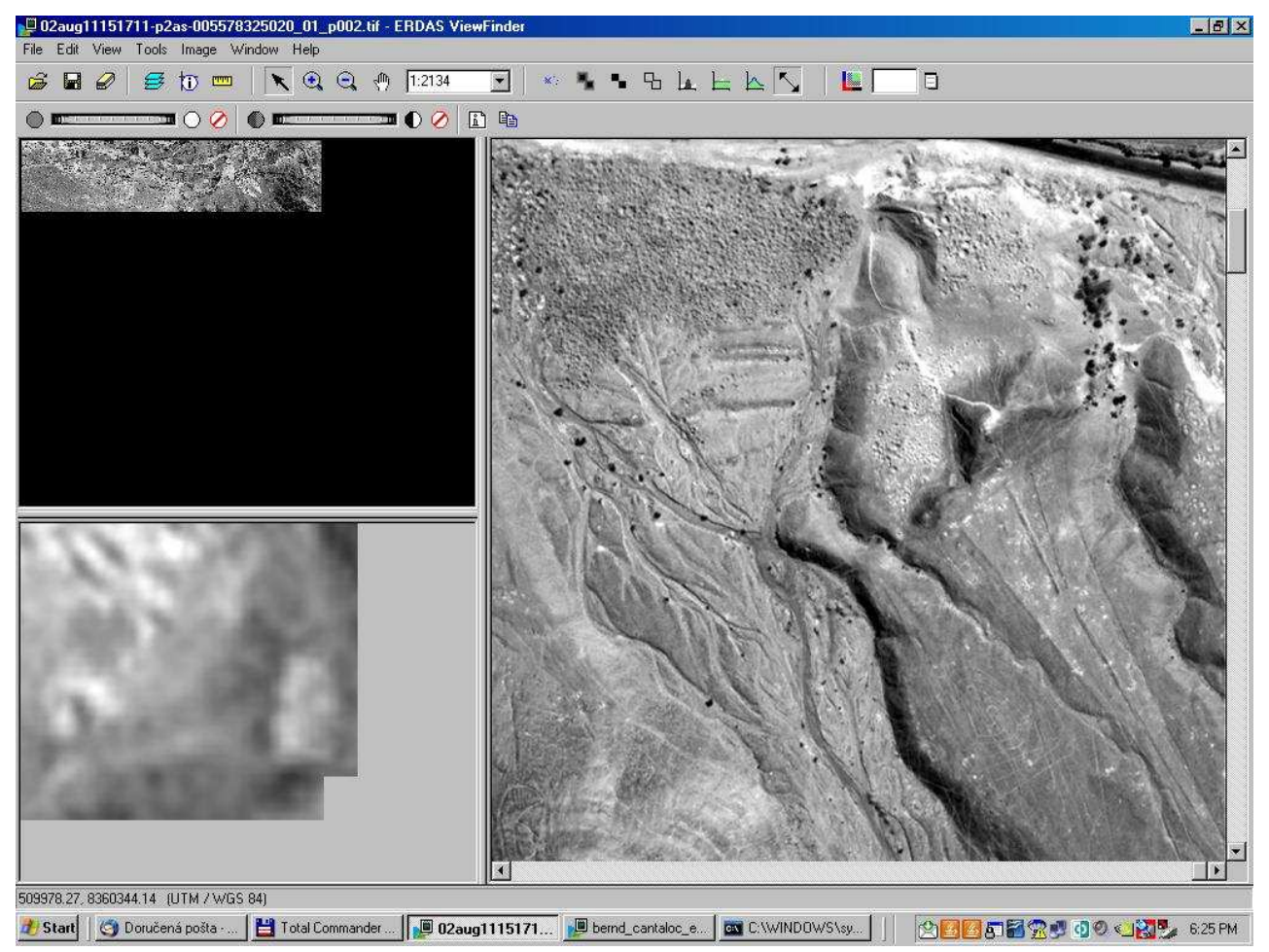

Figure 5. The same geoglyph as in Figures 3-4, but from Quickbird. Courtesy - archive Prof. B. Teichert et al 2009.

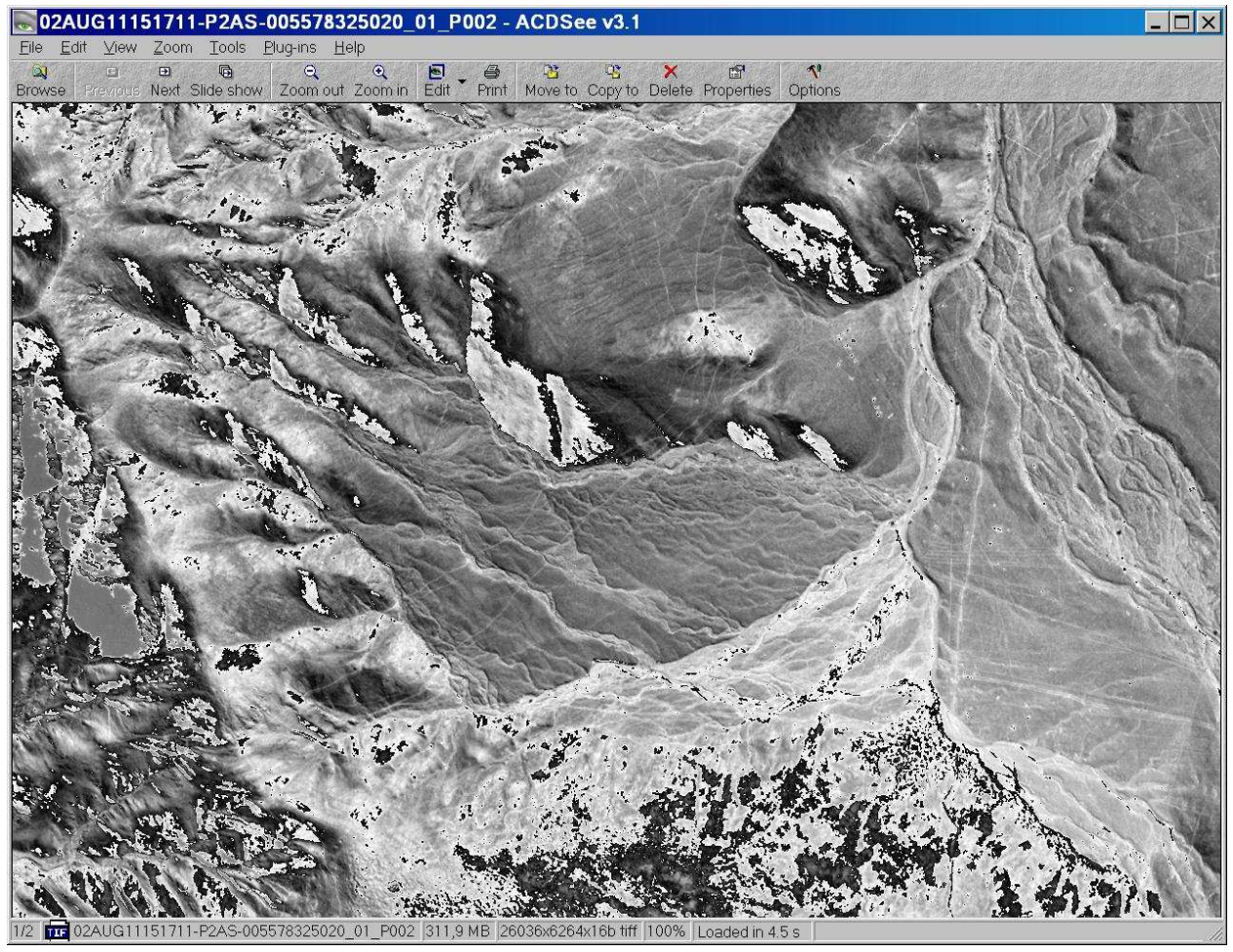

Figure 6. Further geoglyphs and long rays in a remote are in Cantayoc (from the road to Nasca in roughly south direction). Courtesy - archive Prof. B. Teichert et al. 2009. 


\section{ORIENTATION OF CHINESE PYRAMIDS}

The use of the magnetic compass in China is documented from at least the Han dynasty (roughly 200 BC - 200 AD), but may be older. Geomancy (feng shui), practised for a long time, had a profound influence on China's landscape and city plans. The tombs ("pyramids") near Xi'an (also written Sian) and Luoyang, together with the surrounding fields and roads, have varied geographic orientations, some-times in the basic south-north direction, but sometimes with departures up to $25^{\circ}$ (typically $5-10^{\circ}$ ) to the east or west; see three examples in Figs. 8 and 10 (west deviation) and Fig. 9 (east). The use of a compass implies that its needle was directed to the magnetic meridian at the time of construction or last reconstruction of the given tomb. The magnetic pole, however, relative to the 'fixed' geographic pole, wanders significantly in time. Its paleomagnetic declinations for the places and time needed are shown in Fig. 7 [based on Korte, priv. communs., 2007-8]. Using this data we successfully correlated the age of the pyramids with respect to the contemporary magnetic declination [11]. As in Mesoamerica, where according to Fuson's hypo-thesis, [12], [13], the Olmécs and Maya oriented their ceremonial centers by a (lodestone) compass even before the Chinese [14], here in central China the same or a similar technique may have been used. The agreement of building alignments with likely magnetic meridian positions at the time is fairly good [11], Fig. 7. There are indications [ibid] that=knowledge of the compass in China goes back further than the Han period, but the accuracy of paleomagnetic declinat-ions is poor, precluding a good correlation and a definitive conclusion.

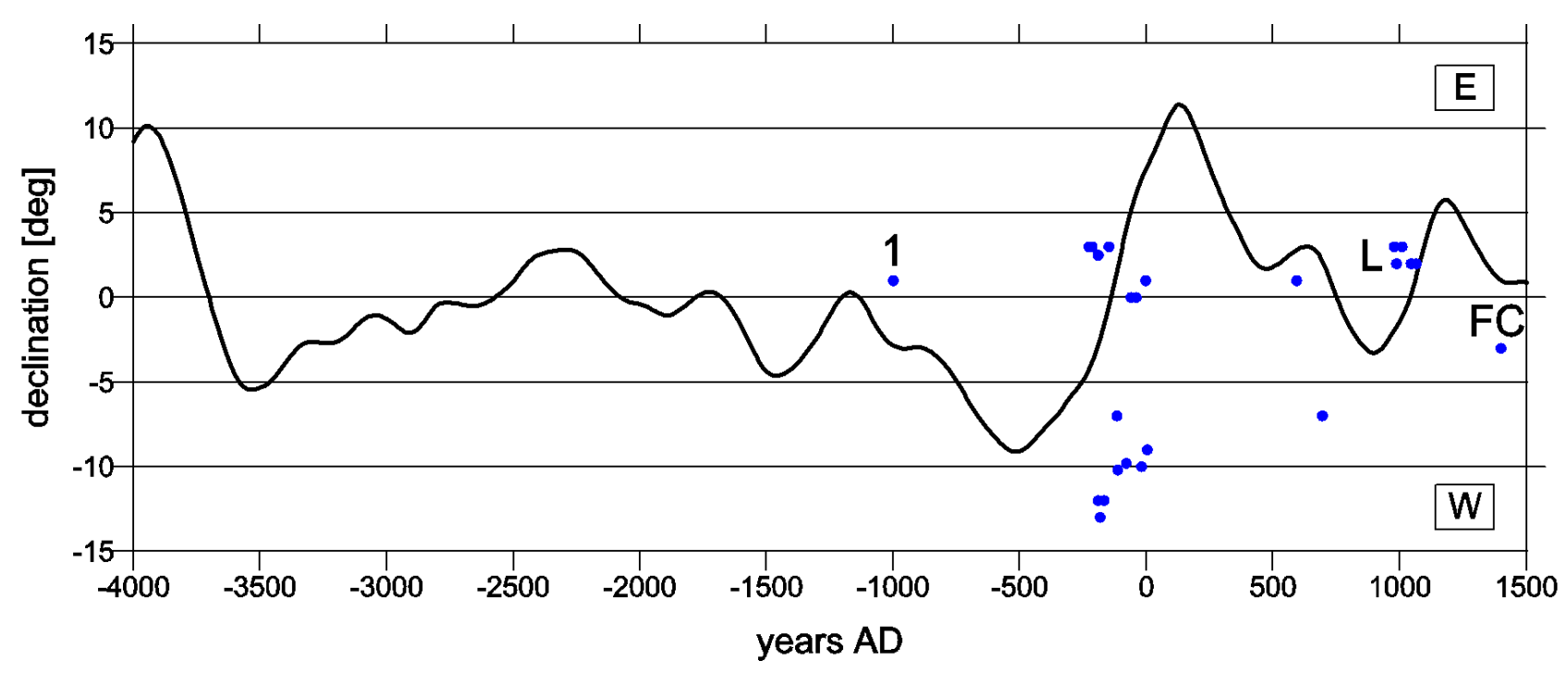

Figure 7. Paleomagnetic declination (curve) for the pyramids in the region of central China (dots), according to Korte's model (for references see [11]) for the period $4000 \mathrm{BC}$ to $1500 \mathrm{AD}$. The declination is plotted in degrees; positive values are to the east.

The precision of Korte's model has been estimated by its authors to be about $5^{0}$, so we can imagine a belt for standard error $\pm 5^{0}$ around the curve.

The number 1 is the oldest object in our set (Mausoleum Kangwang, Western Zhou dynasty, emperor Kangwang, 1004 - $967 \mathrm{BC}$ ), the symbol L stands for the area of the town of Luoyang (east of Xi'an) and FC for the Forbidden City, Beijing. For more details see [11]. 


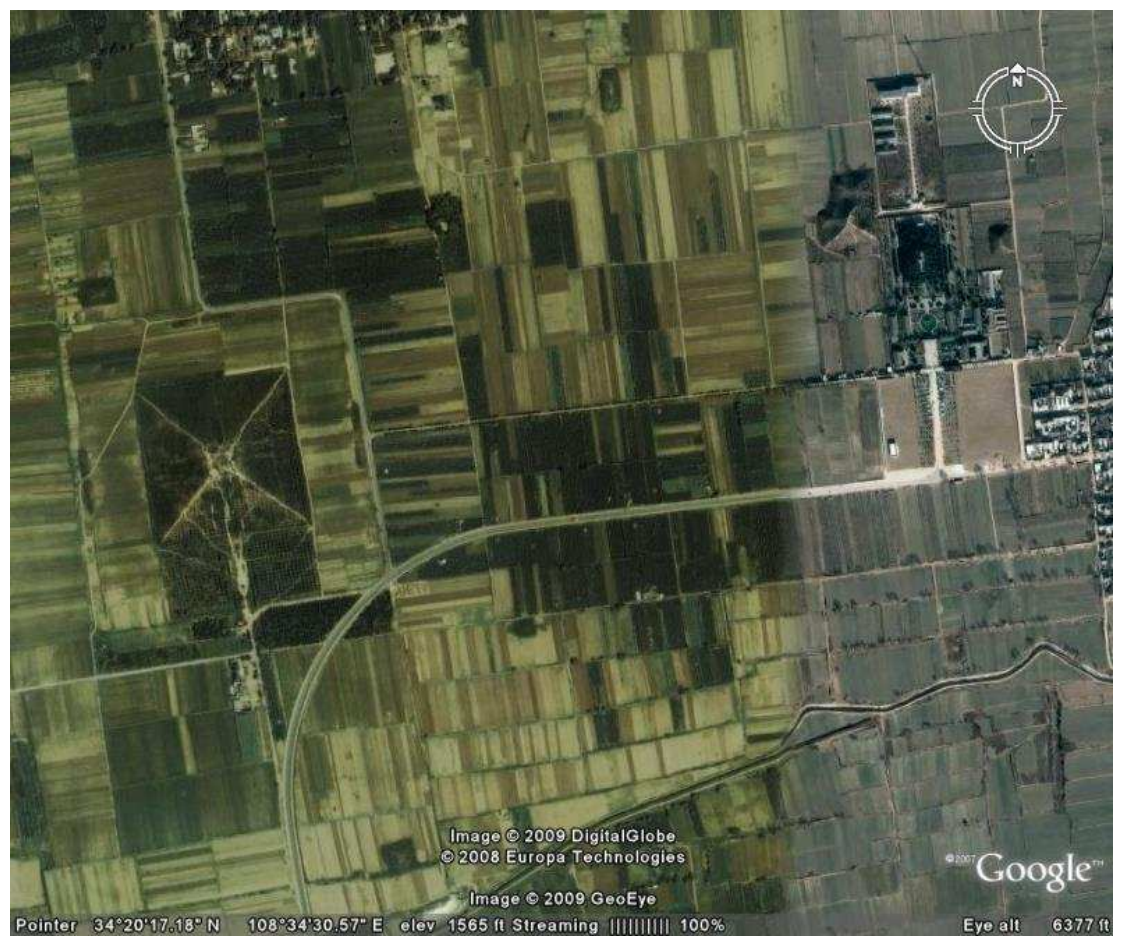

Figure 8. Mausoleum Maoling (the pyramid on the left), Xi'an area, dynasty Western Han, emperor Wudi, 140-87 BC; eye altitude about $2 \mathrm{~km}$, size $230 \times 230 \mathrm{~m}$, height $\sim 70 \mathrm{~m}$, orientation $8^{\circ}$ west of astronomical north, geodetic latitude and longitude (top of the pyramid): $\varphi=34^{\circ} 20^{\prime}, \lambda=108^{\circ} 34^{\prime} \mathrm{E}$.

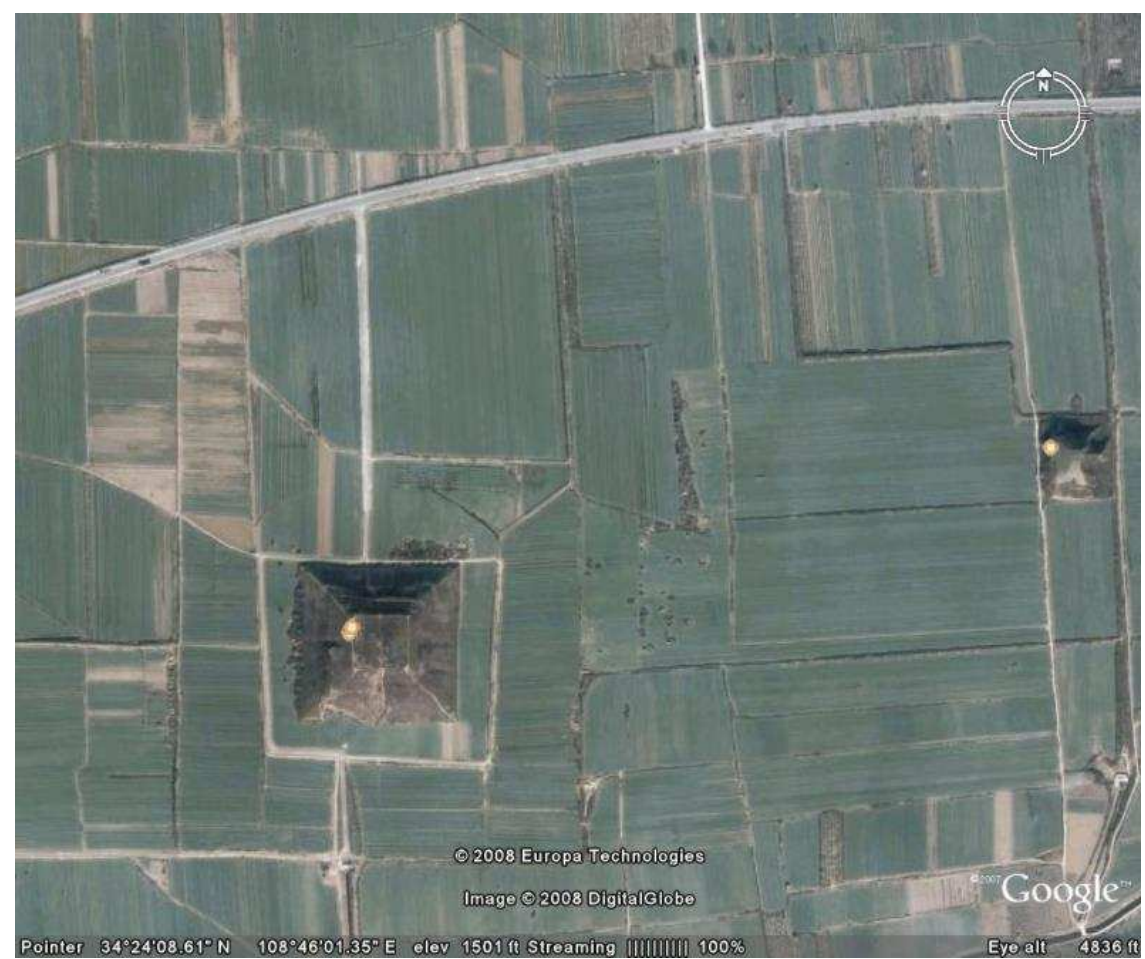

Figure 9. Site called Tailing, Xi' an area, dynasty Sui, emperor Wendi, 581-604 AD; eye altitude about 1.6 $\mathrm{km}$, size $170 \mathrm{~m}$, height $\sim 20 \mathrm{~m}$, orientation $02^{\circ}$ east of north, $\varphi=34^{\circ} 24^{\prime}, \lambda=108^{\circ} 46^{\prime} \mathrm{E}$. 


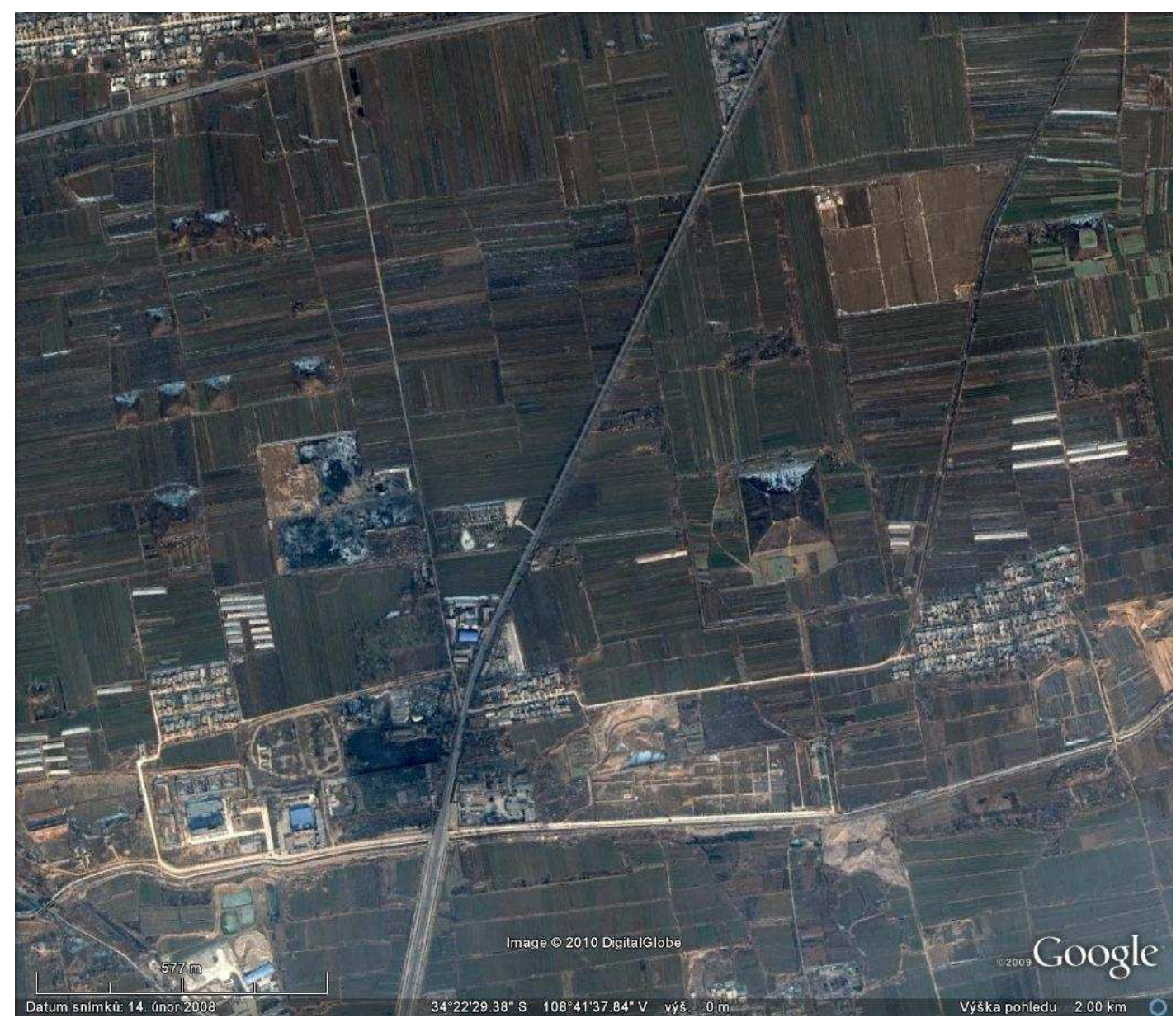

Figure 10. Yangling and a row of pyramids, Xi'an area, dynasty Western Han, emperor Chengdi, 32-7 BC, altitude about $1.6 \mathrm{~km}$, size $170 \mathrm{~m}$, orientation $10^{\circ}$ west, $\varphi=34^{\circ} 22^{\prime}, \lambda=108^{\circ} 42^{\prime} \mathrm{E}$.

GE proved to be very useful in central China: without actually taking measurements on site, we were able to make good estimates of building orientation (within \pm 1 degree). This is an inspiration for search in other and remote areas (provided that the GE resolution is high enough) and for possible future field works.

\section{4. „MONTE ALBAN II“ (ATZOMPA), MEXICO}

Monte Alban is an excellent example of Zapotec culture located near the town of Oaxaca in the mountains of the state of Oaxaca, Mexico; the majority of the buildings visible now are from about 100-300 AD, but some are much older Figures 11 a,b show terrestrial and airplane views, Fig. 12 via GE. The building J of a special shape (Fig. 11b) is als s called "astronomical observatory", see the discussion in, e.g., [15], and its orientation can now be easily checker using GE, see our Fig. 12. The next hill north of Monte Alban also has extensive ruins. GE helps to see the exnasse of it, a pyramidal object surrounded by other ruins and with a "square" (plaza), Figs. 13 a,b. A closer inspectisı on the ground was needed and we had a chance to visit this place in spring 2010 (see Figures 14 - 16). Meantime we received images from TerraSAR-X satellite with better resolution than on GE (another manuscript in preparation). 

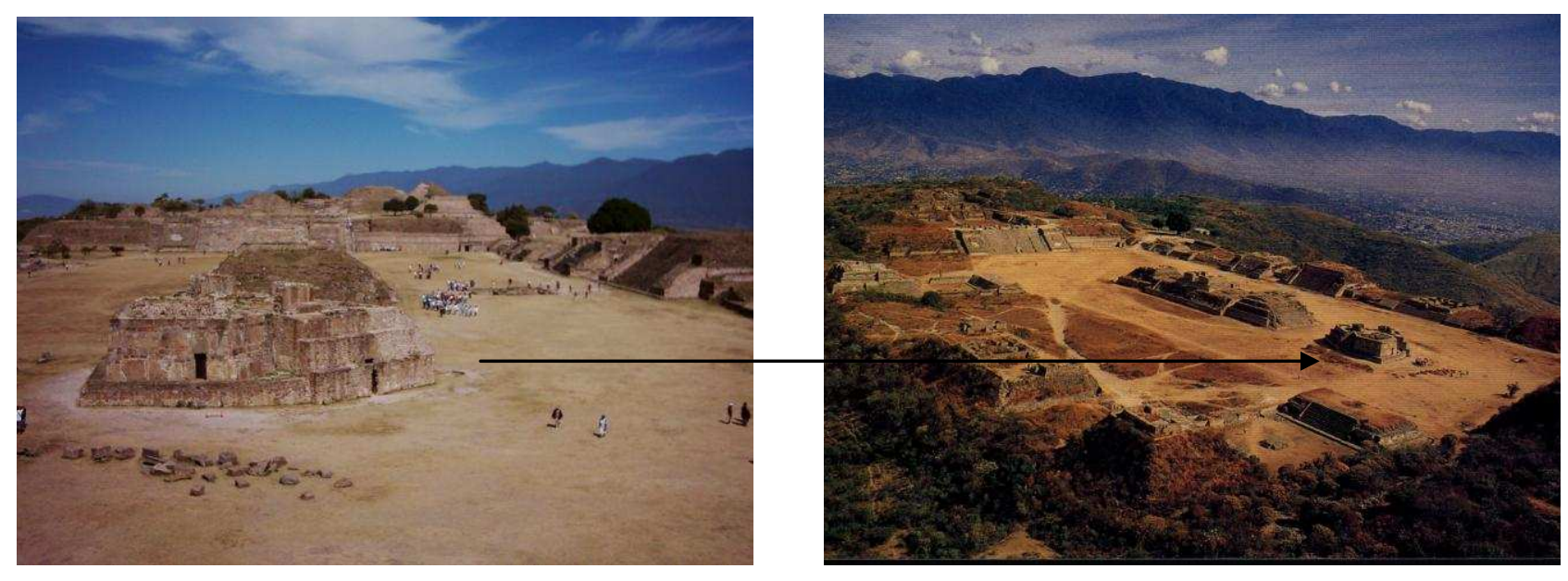

Figures 11 a (left),b (right). Monte Alban locality, Oaxaca, from an aircraft (left), reproduced from a postcard; the building $\mathrm{J}$ is on the main square; ground photo of this object from nearby pyramid (right), C J. Klokočník, 2003

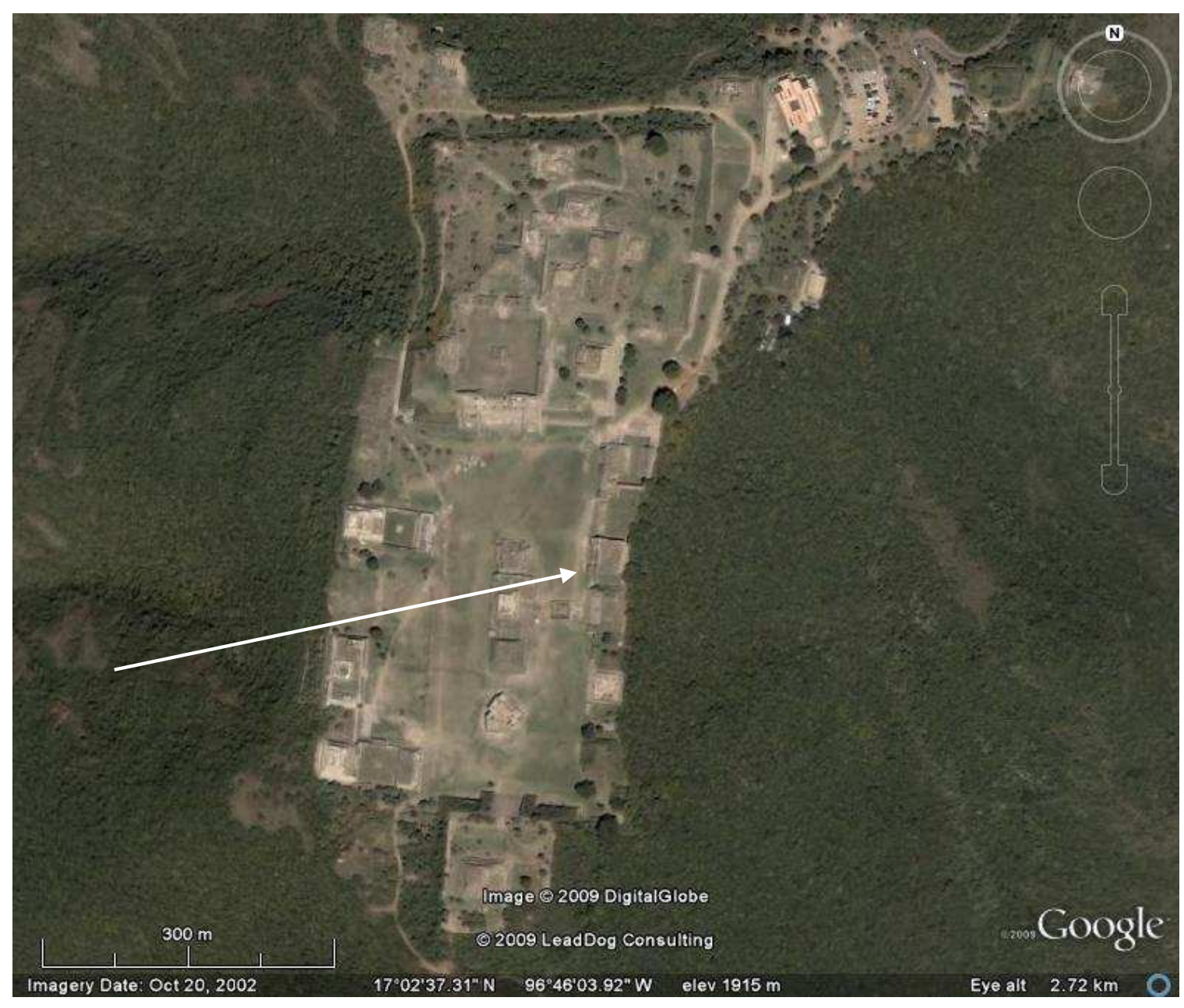

Figure 12. Monte Alban locality from GE, the building J denoted by an arrow. 


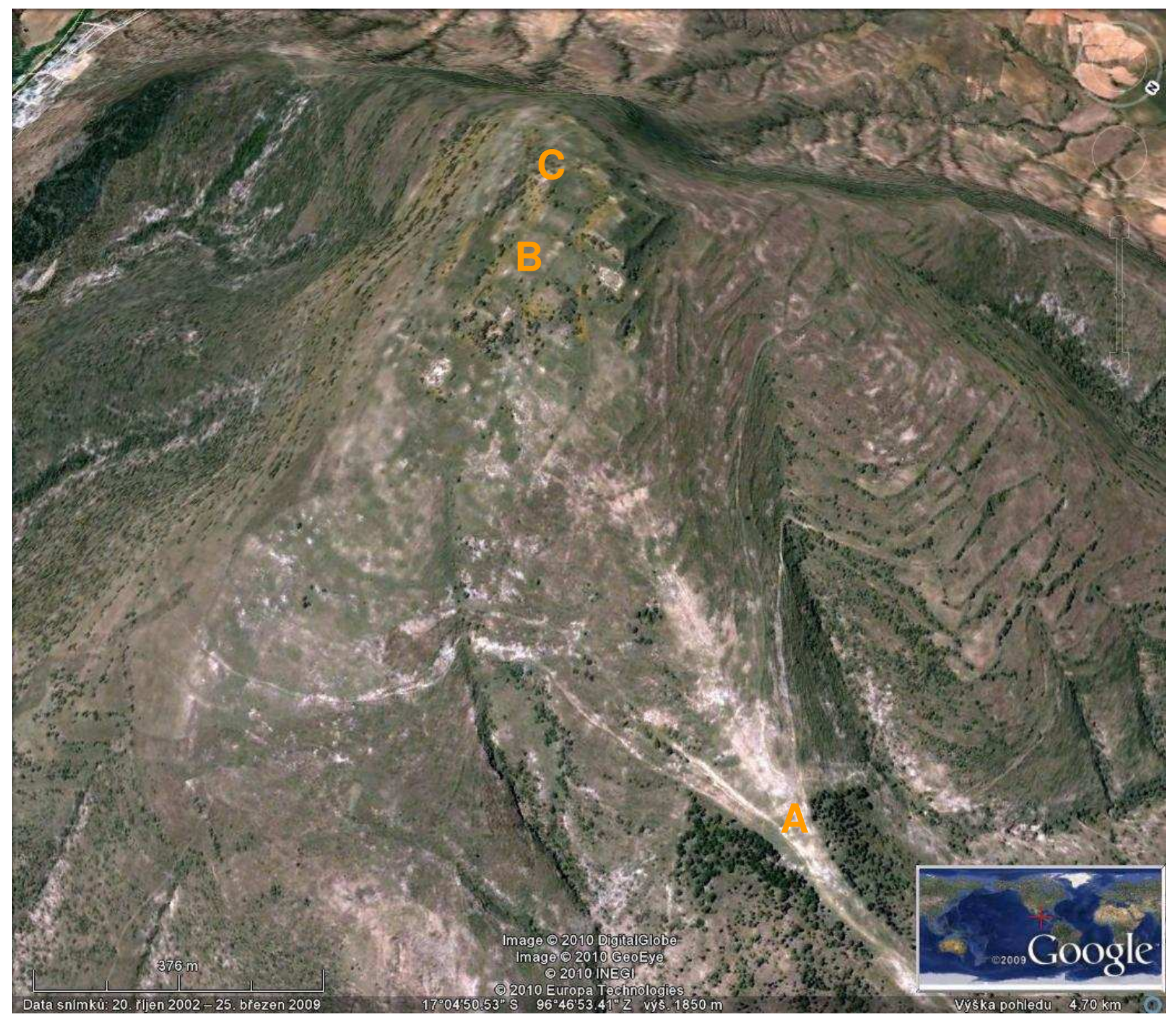

Figure 13 a. 


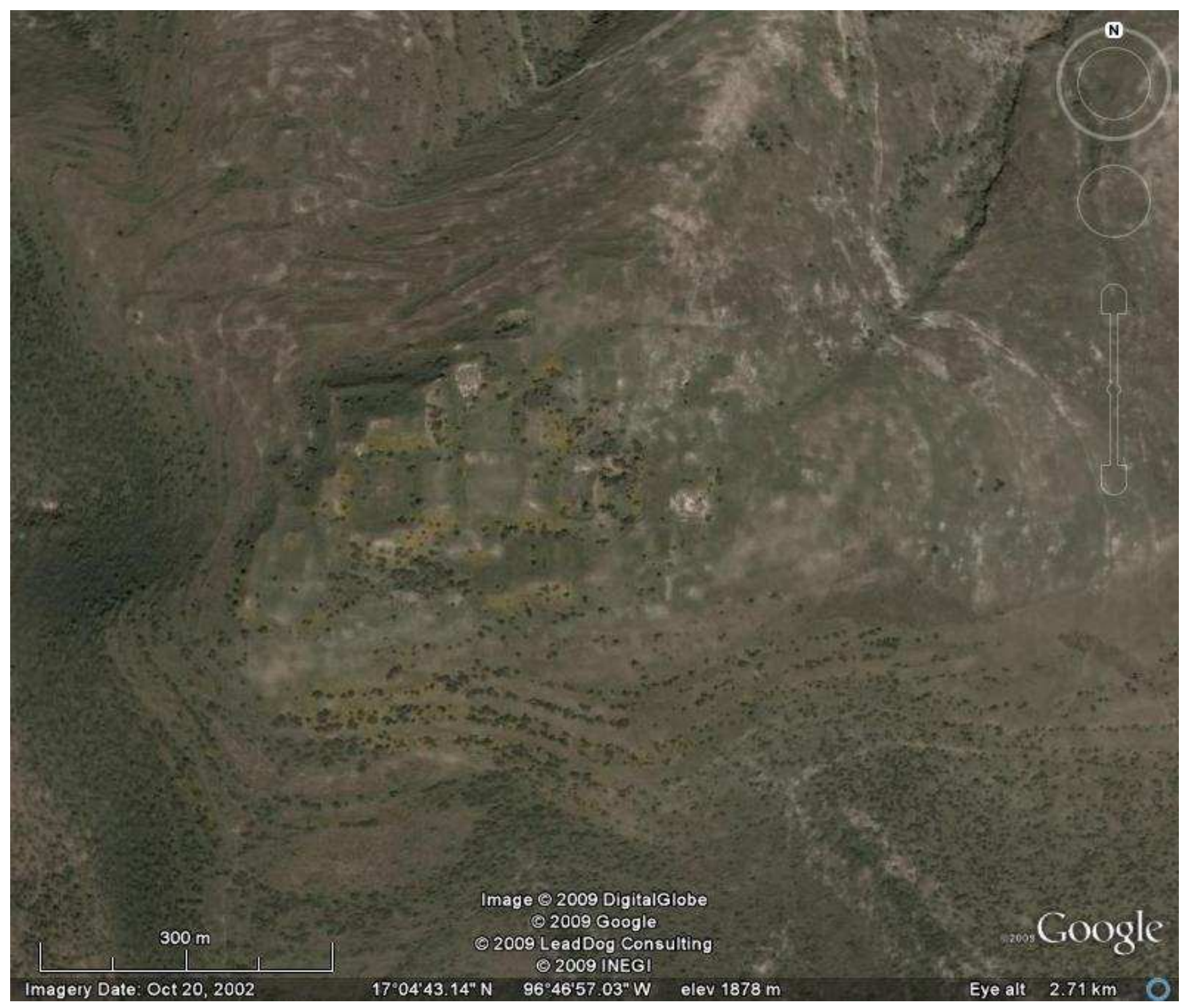

Figures. 13 a,b. Atzompa as seen by GE (images are a little bit old, from 2006). The "3D view" in Fig. 13a is from north-east. The photos in places labeled A, B, C were taken from the ground, see Figures $14-16$.

The Santa María - Atzompa locality is under archaeological research and reconstructions and prepares for tourists. In Figs. 13 a and 13b we show what one can see by GE (status spring 2010). Note labels A, B, and C on Fig. 13b. Then Figures 14-16 show some details photographed from the ground (in March 2010): A .... is the road leading to Atzompa hill from the nearby village (and Oaxaca) to the future parking place, B ... reconstructed plaza below the pyramid, C ...the pyramid - the highest point of Atzompa. All these structures were visible by GE before our visit on the spot. 


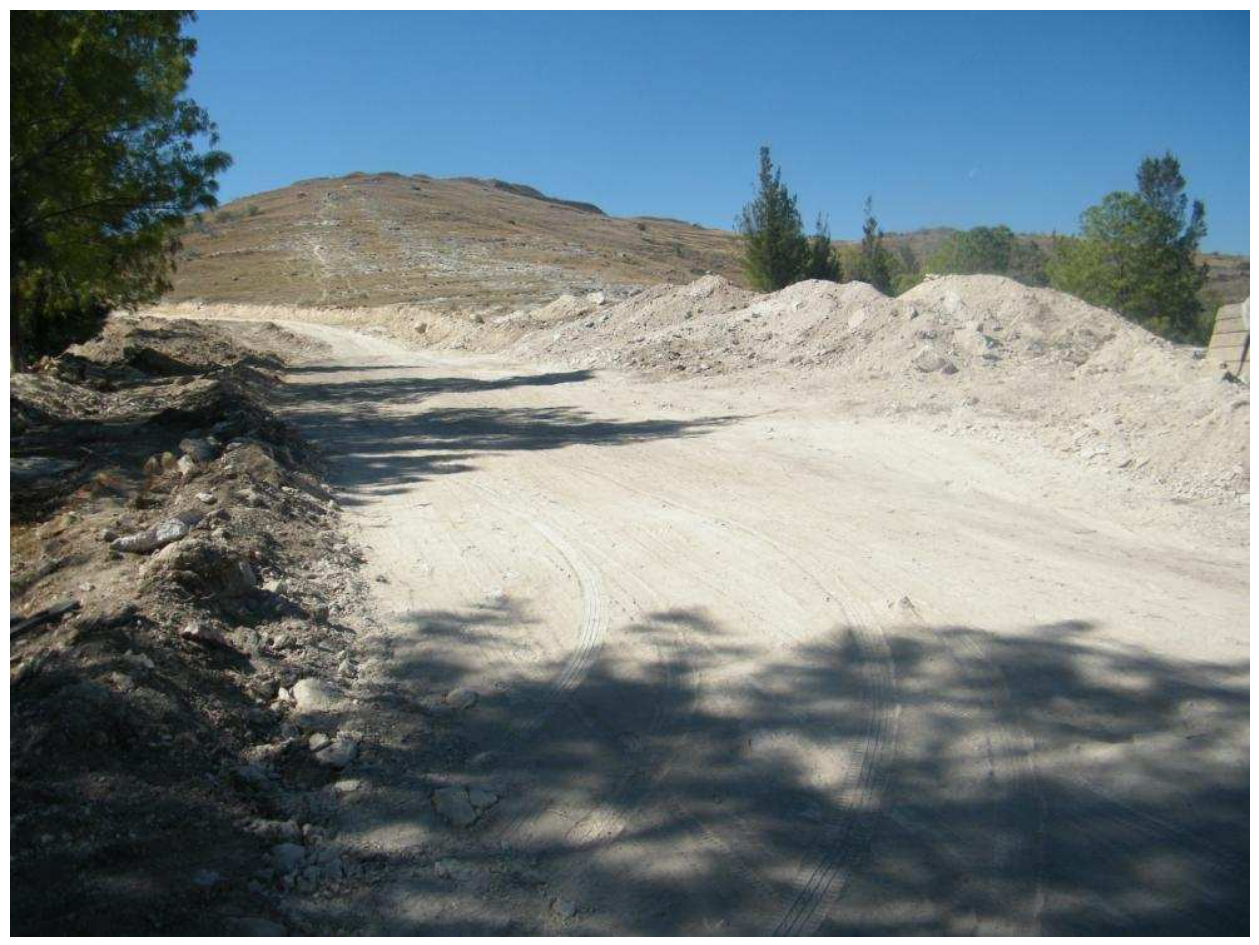

Figure 14. The road to the archaeological locality Santa-María Atzompa in construction; A in Figure 13a, status March 2010, C J. Klokočník, 2010.

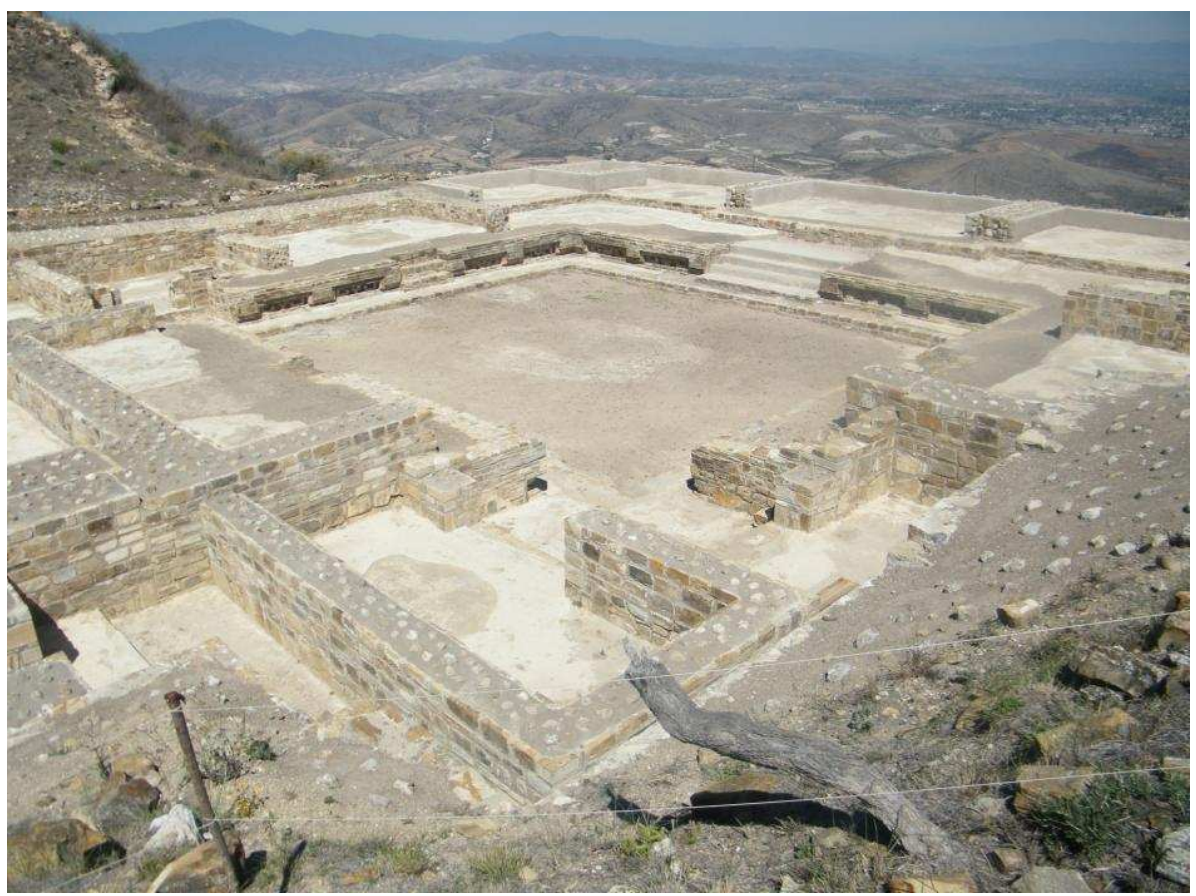

Figure 15. A plaza east of the upper pyramid in Atzompa, in reconstuction; ; B in Figure 13a, status March 2010, (C) J. Klokočník, 2010. 


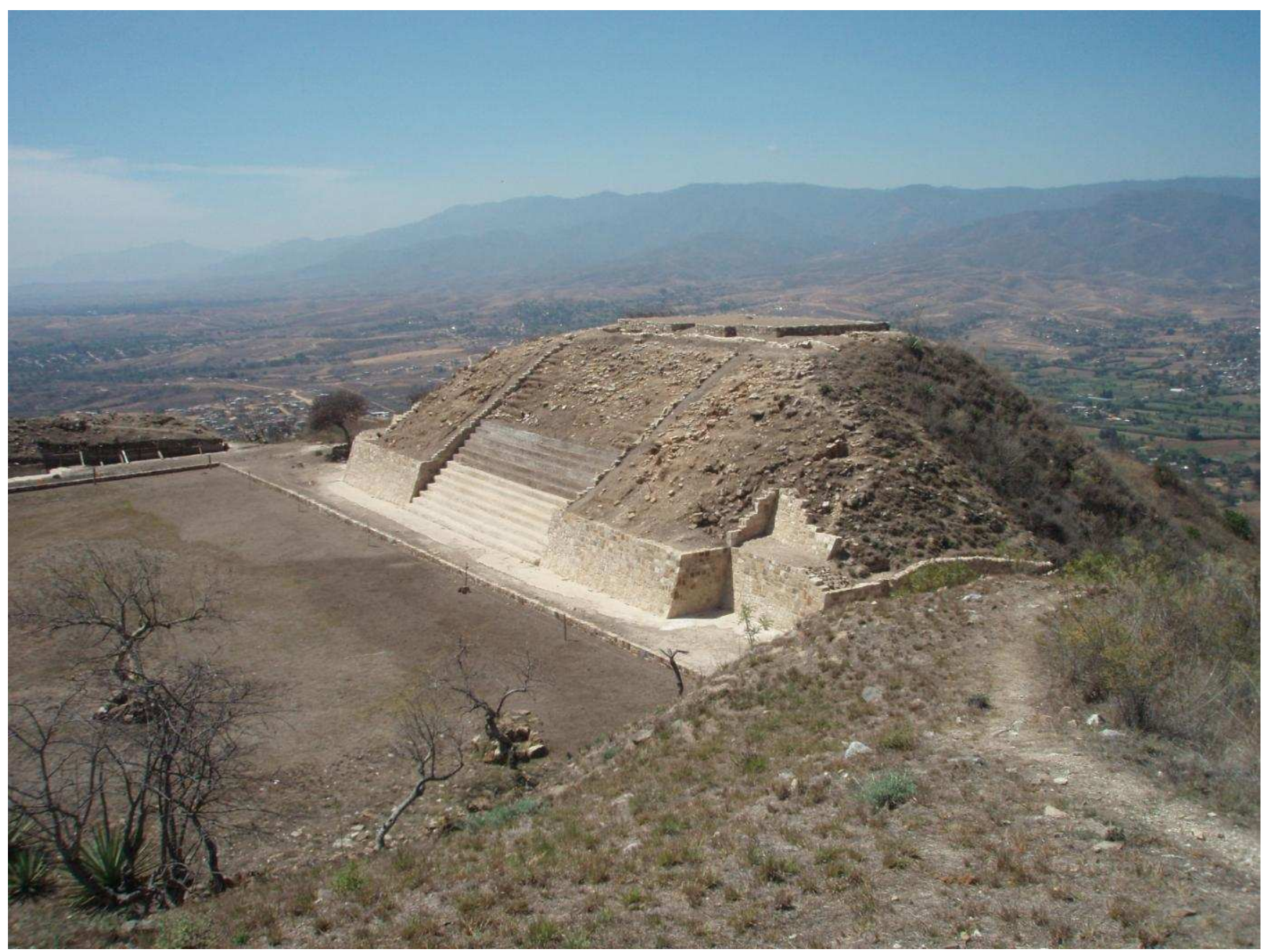

Figure 16. View from the top of the highest pyramid of Atzompa to the plaza in south direction and to a smaller pyramid in south-west direction, ; C in Fig. 13a, in reconstruction; status March 2010, (C) J. Klokočník, 2010.

\section{SACBEOB}

Sacbeob (plural of sacbe) mean "white ways" and they are roadways, causeways, raised paved roads (coated with limestone stucco) that were built by the Maya civilization. Most connect temples, plazas, and groups of structures within ceremonial centres or cities, but some are much longer and connect cities (e.g., around Cobá or between Uxmal and Kabáh). They apparently had practical and ritual or religious significance as well. Many sacbeob can now be used by tourists (e.g., at Chichen Itzá, Uxmal, Cobá, Dzibilchaltún), but many others are hidden in the jungle and may lead to undiscovered ruins. They are visible by GE because the colours of the vegetation and its reflectivity differ from the surrounding forest (see Fig. 17c). 

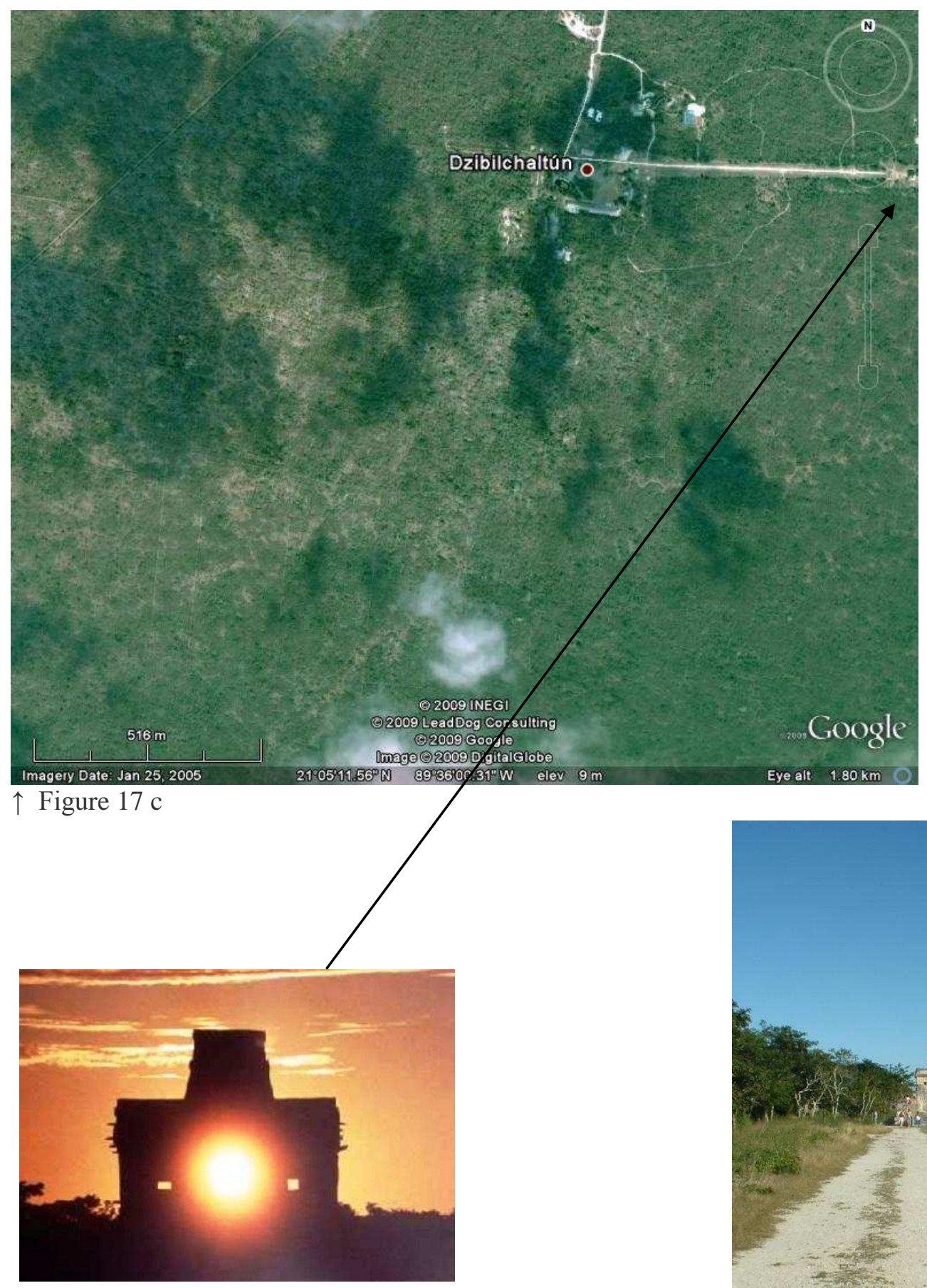

Figure $17 \mathrm{a}, \mathrm{b}$

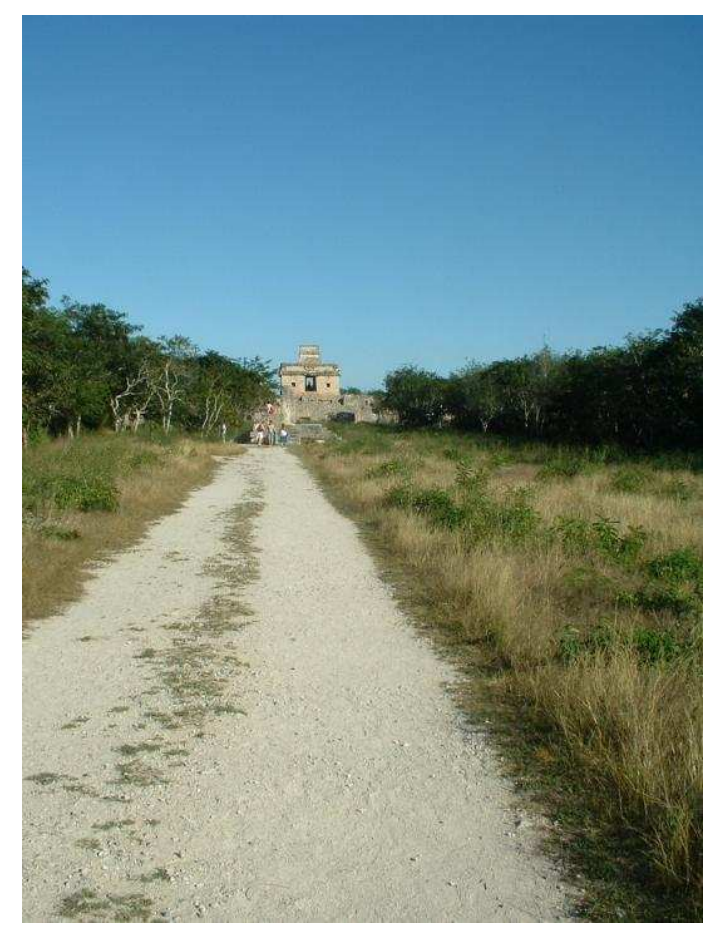

Figures 17 a,b. Sacbe to the Temple of Seven Dolls (or Structure 1) in Dzibilchaltún (north Yucatán), from west to east, and the Temple itself, showing its astronomical orientation in autumn equinox. Ground photo by (C) J. Klokočník, 2005.

Figure 17c. Sacbeob "network" in the vicinity of Dzibilchaltún, visible by GE, not the only sacbe to the temple of Seven dolls, but many hidden roadways in the jungle. Sometimes the new roads follow the ancient sacbeob. 


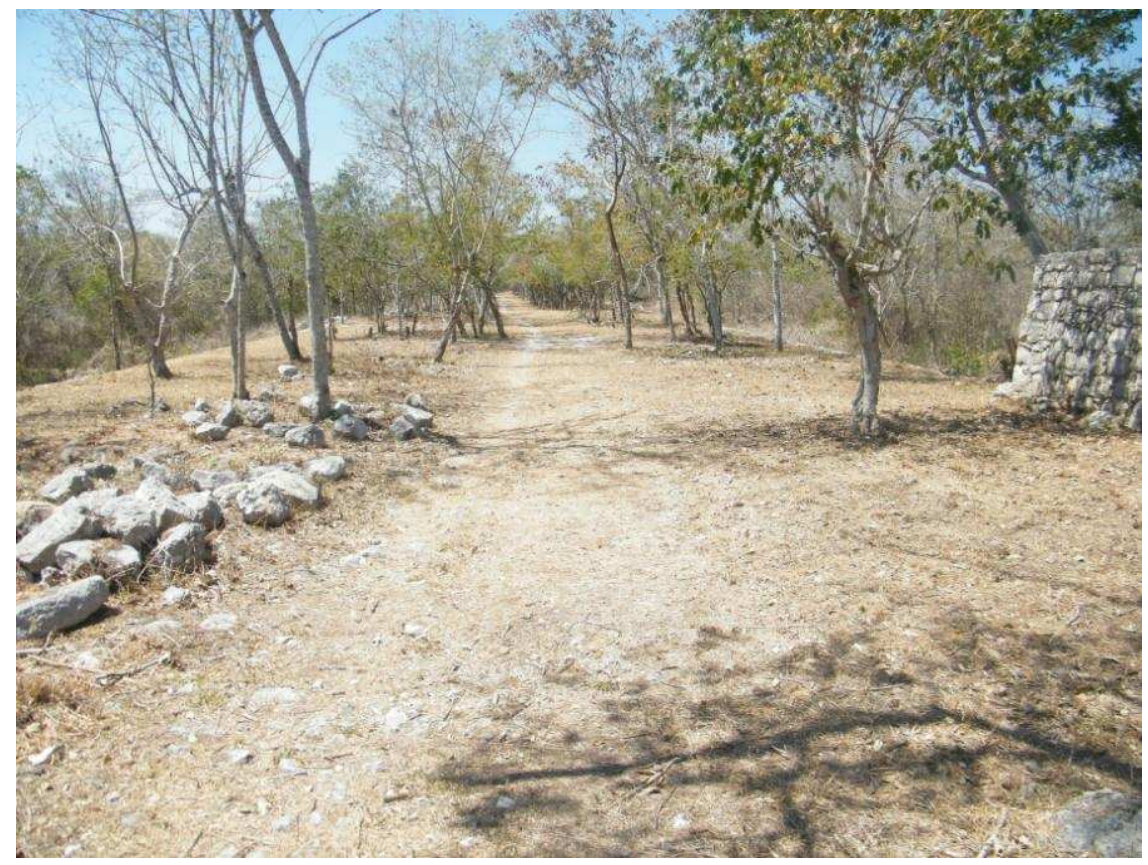

Figure 18. Sacbe in east-west direction (a continuation of sacbe in Fig. $17 \mathrm{a}$ in the west direction), crossing the central plaza in Dzibilchaltun. (C) J. Klokočník, 2010.

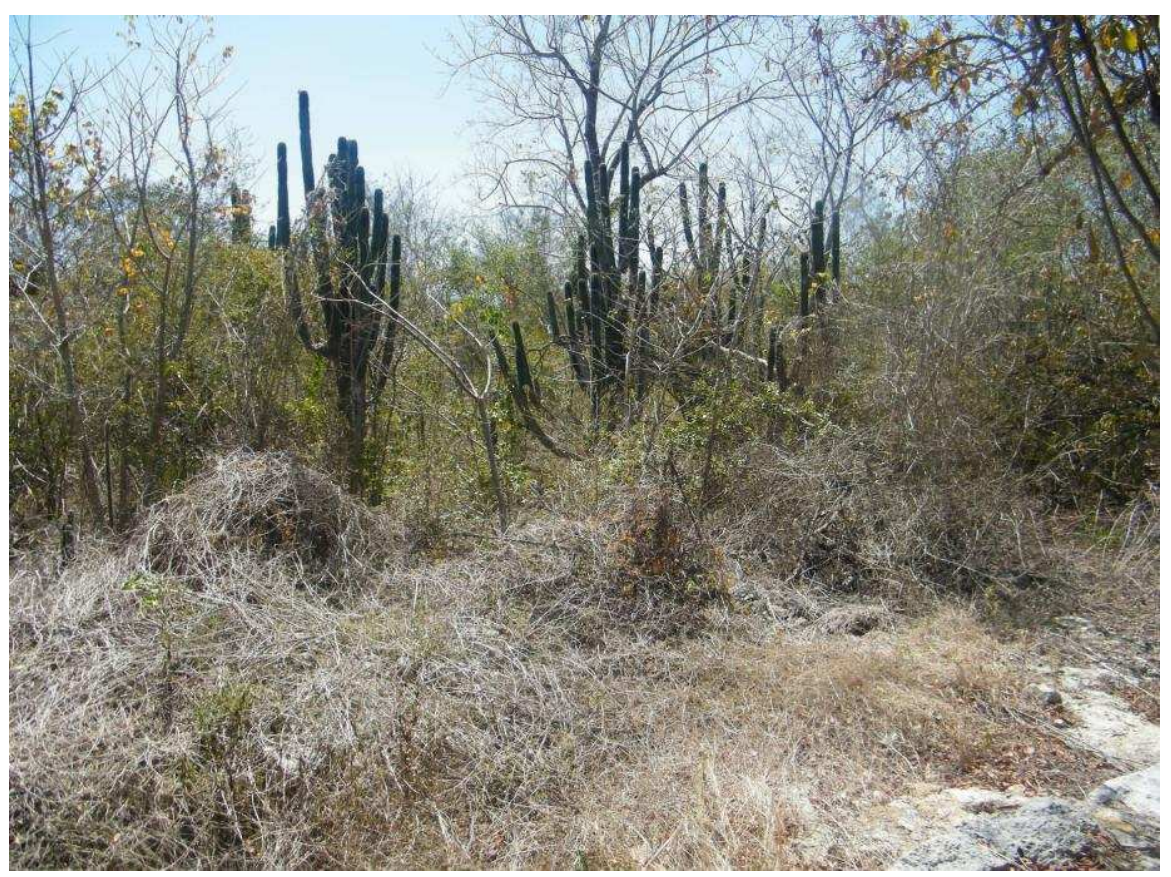

Figure 19a. Sacbe hidden in selva ("forest"), the area of Dzibilchaltún. Photo from the ground, (C) J. Klokočník, 2010. 


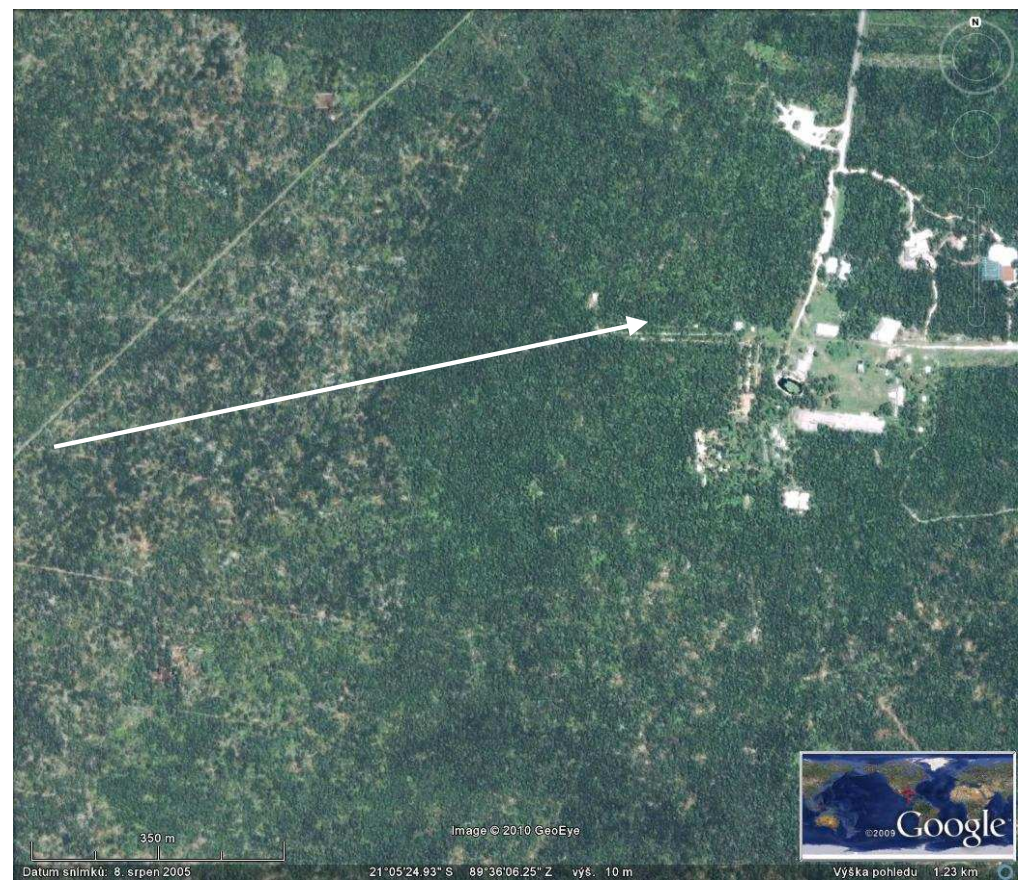

Figure 19b. The same place on the sacbe, as in Fig. 18, as identified by GE (arrow).

\section{CHACO ASTRONOMY}

The Chaco culture, 850-1130 AD, now in New Mexico, USA, seems to have made accurate observations of the Sun, the Moon, the planets, selected bright stars, comets and bolides, etc. beyond what were necessary for practical purposes such as creating astronomical calendars (for tracking the planting seasons). The locality has been extensively investigated by Sofaer and her group [16]. They proposed that the largest towns in the Chaco valley, such as Pueblo Bonito (Fig. 20) with several-story buildings and underground structures (kivas), were devoted to ceremonials and that the area can be called a "pilgrimage centre"; it was sparsely inhabited, but visited at certain times by many people from surrounding villages. Pueblo Bonito and other villages have internal and mutual astronomical orientation, too. Sofaer and coworkers provide extensive documentation about these aspects.

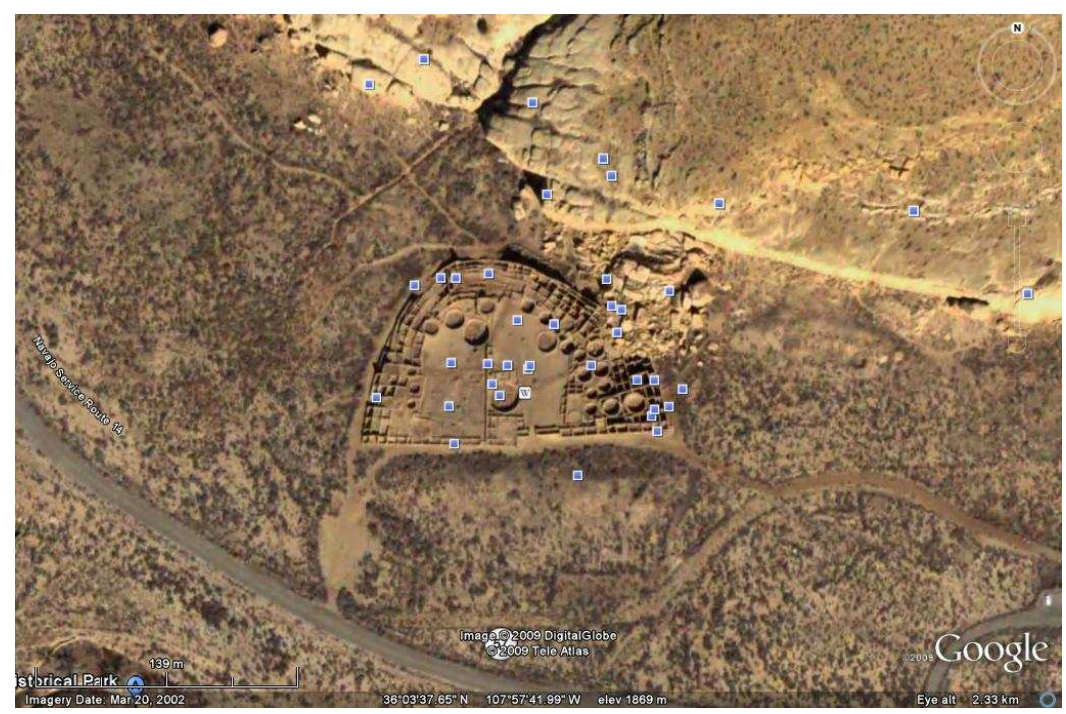

Figure 20. Chaco Pueblo Bonito by GE 
The most important place is the so called Sun Dagger on the Fajada Butte (Fig. 21) near the Chaco valley. There, nearly on the top of the Butte (rock), are certain slabs whose positions cause the light to spiral onto a nearby rock, specifically at the solstices and equinoxes. Around the Chaco valley there are long straight (ray-like) ancient roads, which certainly served practical purposes; but others go "nowhere", so the hypothesis is that they are the expression of spiritual values, they may have a cosmo-logical meaning [16]. We used GE and saw many straight long lines north and south of the Chaco valley over a very large area, largely similar to what we saw in Peru. Some of others go "nowhere", so the hypothesis is that they are the expression of spiritual values, they may have a cosmo-logical meaning [16]. We used GE and saw many straight long lines north and south of the Chaco valley over a very large area, largely similar to what we saw in Peru. Some of the "roads", however, might be artifacts at the edges of connecting sheets of GE maps (one must be very careful). Fig. 21 illustrates the dilemma, where some (but not all) "roads" may be real. We guess that the feature in Fig. 22 (a narrow "road" crossing a valley) is not an artifact (no edges of map lists). In general they need further inspection on the spot.

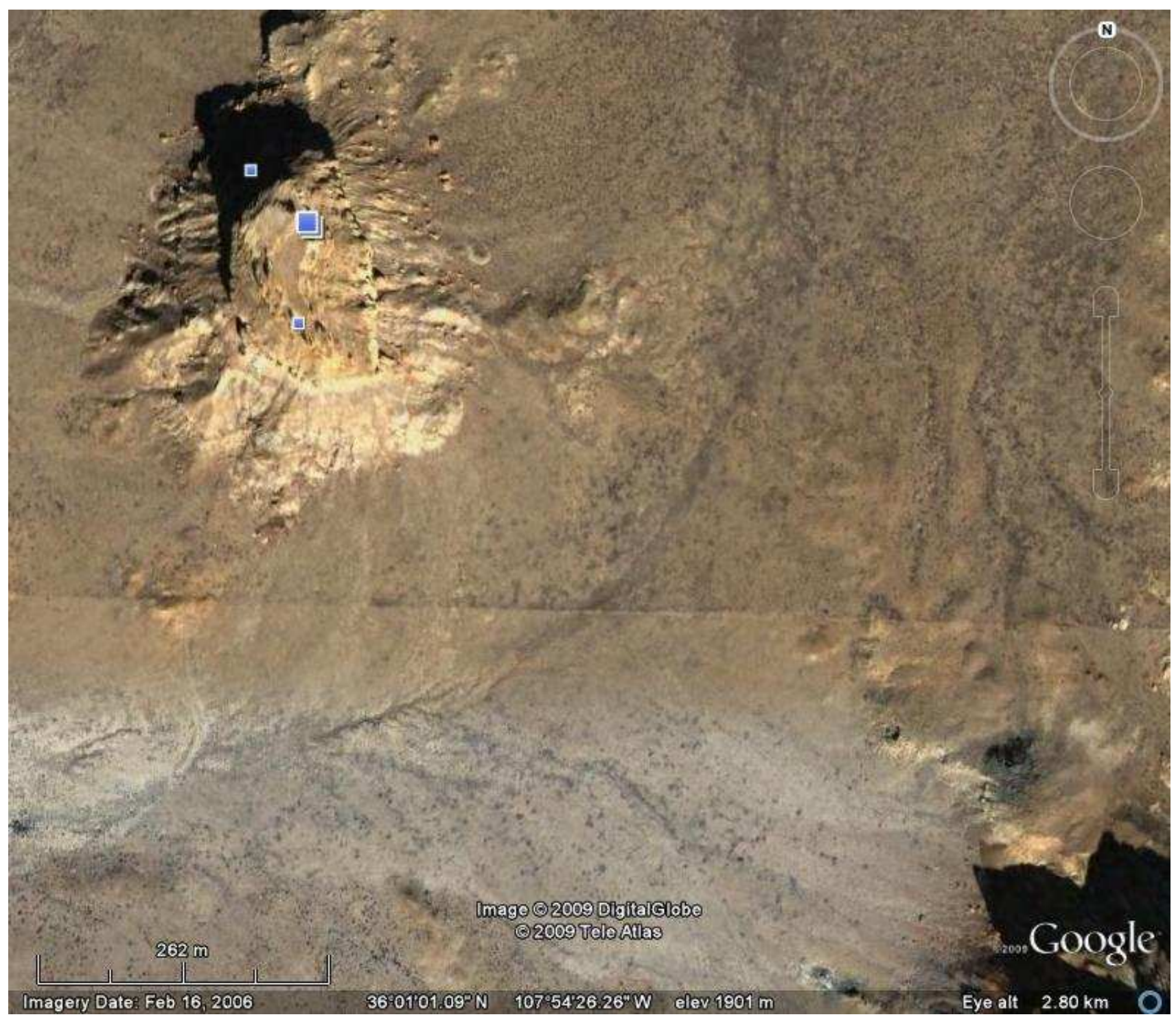

Figure 21. Artifact or reality? Long ray (a path?) near Fajada Butte among many similar long lines in that area, where sometimes ancient and new roads go closely together; in this case artefact at the edges of connecting sheets of Google Earth maps. 


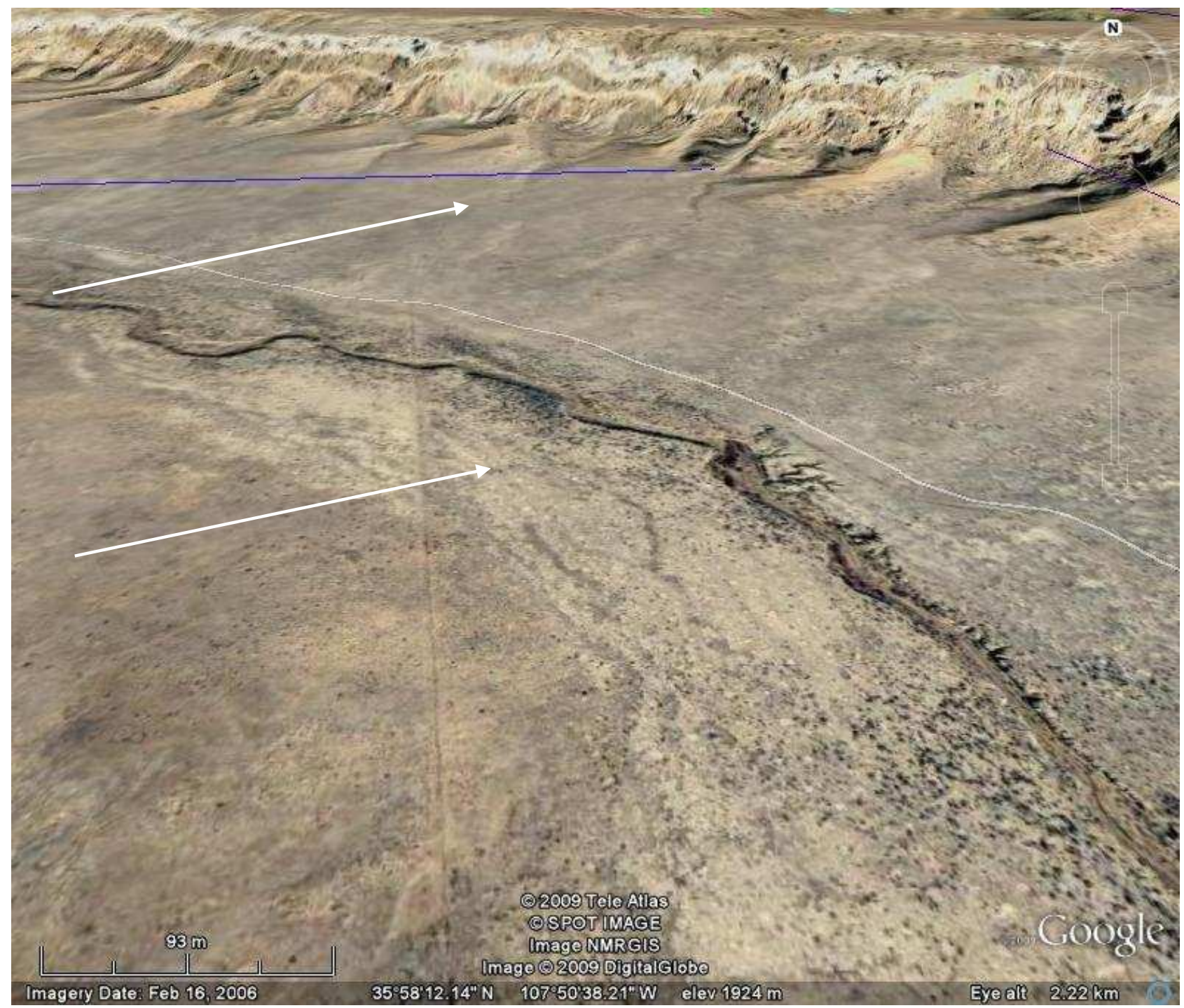

Figure 22. Artifact or reality? A long ray near Chaco valley, among many similar long straight lines in that area, Google Earth, 2009.

\section{CONCLUSION}

Google Earth has proved a very useful tool for studying some aspects of various ancient cultures, before, during and after field measurements, making these studies much easier to carry out. We have shown its value in several such areas - Nasca geoglyphs in Peru, buildings and roads in Mesoamerica or Chaco culture in North America. A particular discovery, concerning Chinese temple-pyramids, illustrates GE's utility with promising future possibilities: their aerial views show orientations making it highly probable that the layout of the ceremonial fields was made with a magnetic compass. Looking ahead, we plan further studies of Atzompa and the sacbeob system with the aid of more detailed satellite images. There are, of course, many localities of archaeo-astronomical significance, worthy to be investigated by GE or other satellite images. The purpose of this report is modest - to present a few examples that may attract the attention of other researchers. 


\section{ACKNOWLEDGMENTS}

We thank anonymous reviewers for improving our manuscript, Dr. R.H. Gooding (Farnham, Southern England) for improving our English and Prof. B. Teichert (HTW Dresden, FB Vermessung/Kartographie) for a sample of IkonosQuickbird images from the Nasca area.

\section{REFERENCES}

[1] D. Potere, "Horizontal Positional Accuracy of Google Earth's High Resolution Imagery Archive”, Sensors, vol. 8, 2008, pp. 7973-7981, doi: 10.3390/s8127973.

[2] J. Klokočník and J. Kostelecký, "Google Earth for the Study of Ancient Civilizations“, presented at the „2010 Second International Conference on Advanced Geographic Information Systems, Applications, and Services“, (C) 2010 IEEE

DOI 10.1109/GEOProcessing.2010.16

[3] M. Reiche, "Mystery on the Desert Nasca, Peru", Assoc. Maria Reiche for the lines of Nasca, reedition 1996, Nasca, Peru.

[4] D. Johnson, "Beneath the Nasca Lines and other Coastal Geoglyphs of Peru and Chile", Global Learning, Inc., Pough-keepsie, NY, 2009. See also: www.museum-albersdorf.de/nazca.

[5] K. Schreiber, J. L. Rojas, and S. Barbara, "The Water Systems of the Nasca Culture“, Nasca Symp. 2006, Bielefeld, Germany, Dresdner Kartogr. Schriften, eds. B. Teichert and Ch. Rust, HTW Dresden 2007, pp. 43-54.

[6] P. Kosok, "Life, Land and Water in Ancient Peru“, Long Island Univ. Press, New York, 1965.

[7] B. Teichert, "Astronomical Investigations of the Nasca Lines“, Nasca Symp. 2006, Bielefeld, Dresdener Kartograpische Schriften, eds. B. Teichert and Ch. Rust, HTW Dresden 2007, pp. 87-101.

[8] E. Hadingham, "Lines to Mountain Gods, Nazca and the Mysteries of Peru“, Norman, New York, 1988.

[9] J. Klokočník, F.Vítek, Z. Klokočníková, and R.A. Rodrigues, "Los Geoglifos de Nazca, Perú“, Boll. Inst. RivaAguero \# 29.2002 (BIRA), Pontif. Univ. Católica del Perú, pp. 13-29.

[10] J. Klokočník and K. Pavelka, "Nasca, Peru: El Astronauto is a Fisherman", Ameridian Research, Bd. 5/2, pp. 166-168, ISSN 1862-3867, Dr. M. Koch Verlag, Rogeez, Germany (in German).

[11] I. Charvátová, J. Klokočník, J. Kolmaš, and J. Kostelecký, "Chinese Tombs Oriented by a Compass: Evidence from Paleo-magnetic Pole Changes vs Tombs age", Studia G. et G., 2010 in press.

[12] R. H. Fuson, "The Orientation of Mayan ceremonial centers", Annals Assoc. American Geograph., vol. 59, 1969, pp. 494-511.

[13] K.Pavelka: Topographic and Thematic Mapping from Multi-Resolution Satellite Image. Proceedings of 24th ICA Conference. Santiago: International Cartographic Association, 2009, vol. 1, p. 956-962.

[14] J. B. Carlson, “Lodestone Compass: Chinese or Olmecs Primacy? Science, vol. 189, 1975, 753-760.

[15] J. Klokočník, J. Kostelecký, F. Vítek, "Pyramids and Cerem-onial Centers in Mesoamerica: were they Oriented using a Magnetic Compass?”, Studia G. et G., vol. 51, 2007, pp. 515-533.

[16] A. Aveni, "Skywatchers of ancient Mexico“, Univ. Texas Press, 1980.

[17] A. Sofaer, and contributors to The Solstice Project, "Chaco astronomy, an ancient american cosmology", Ocean

Tree Books, Santa Fe, New Mexico, 2008. 